Chapman University

Chapman University Digital Commons

Food Science Faculty Articles and Research

Science and Technology Faculty Articles and

Research

$1-24-2020$

\title{
Labeling Compliance and Species Authentication of Fish Fillets Sold at Grocery Stores in Southern California
}

\author{
Priscila Liou \\ Chapman University, priscila.liou@gmail.com \\ Angela Banda \\ Chapman University \\ Rachel B. Isaacs \\ Chapman University \\ Rosalee S. Hellberg \\ Chapman University, hellberg@chapman.edu
}

Follow this and additional works at: https://digitalcommons.chapman.edu/food_science_articles

Part of the Aquaculture and Fisheries Commons, Food Biotechnology Commons, Food Microbiology Commons, Food Processing Commons, and the Other Food Science Commons

\section{Recommended Citation}

Liou, P., Banda, A., Isaacs, R.B., Hellberg, R.S., 2020. Labeling compliance and species authentication of fish fillets sold at grocery stores in Southern California. Food Control 112, 107137. https://doi.org/

10.1016/j.foodcont.2020.107137

This Article is brought to you for free and open access by the Science and Technology Faculty Articles and Research at Chapman University Digital Commons. It has been accepted for inclusion in Food Science Faculty Articles and Research by an authorized administrator of Chapman University Digital Commons. For more information, please contact laughtin@chapman.edu. 


\section{Labeling Compliance and Species Authentication of Fish Fillets Sold at Grocery Stores in Southern California}

\section{Comments}

NOTICE: this is the author's version of a work that was accepted for publication in Food Control. Changes resulting from the publishing process, such as peer review, editing, corrections, structural formatting, and other quality control mechanisms may not be reflected in this document. Changes may have been made to this work since it was submitted for publication. A definitive version was subsequently published in Food Control, volume 112, in 2020. https://doi.org/10.1016/j.foodcont.2020.107137

The Creative Commons license below applies only to this version of the article.

A thesis with this title is also available here.

\section{/}

Creative Commons License

(c) (i) (9)

This work is licensed under a Creative Commons Attribution-Noncommercial-No Derivative Works 4.0 License.

\section{Copyright}

Elsevier 
Title: Labeling compliance and species authentication of fish fillets sold at grocery stores in Southern California

Authors: Priscila Liou, Angela Banda ${ }^{\mathrm{a}}$, Rachel B. Isaacs ${ }^{\mathrm{a}}$, and Rosalee S. Hellberga*

${ }^{\mathrm{a} C h a p m a n}$ University, Schmid College of Science and Technology, Food Science Program, One University Drive, Orange, CA 92866

\section{*Corresponding Author}

Rosalee S. Hellberg, Ph.D.

Chapman University

One University Drive

Orange, CA 92866

Phone: (714) 628-2811

E-mail: hellberg@chapman.edu 


\section{Abstract}

2 Seafood mislabeling has numerous consequences, including economic deception and

3 food safety risks. The focus of this study was to investigate fish species labeling, use of

4 acceptable market names, and Country of Origin Labeling (COOL) compliance for fresh fish

5 fillets sold at grocery store seafood counters in Southern California. A total of 120 fillets

6 representing 16 different categories of fish were collected from 30 Perishable Agricultural

7 Commodities Act (PACA)-listed grocery stores. Each sample underwent DNA barcoding to

8 identify the species. Acceptable market names were confirmed using the FDA Seafood List.

9 Samples were determined to be compliant with COOL if both the country of origin and the

10 production method were declared in accordance with regulatory requirements. Species

11 substitution was detected in 16 of the 120 samples $(13.3 \%)$ and unacceptable market names were

12 observed for an additional 11 samples (9.2\%). The highest rates of species substitution were

13 recorded for snapper (3/3), yellowtail (2/4), halibut (4/10), cod (3/10), and bass (2/7). COOL

14 noncompliance was observed for 28 samples (23.3\%): the country of origin was missing for 15

15 samples, production method was missing for 9 samples, and 4 samples were missing both. When

16 all forms of mislabeling were considered, 47 of the 120 samples (39.2\%) had at least one

17 labeling error. The majority of grocery stores (25/30) had one or more samples with a

18 mislabeling error. This study revealed species mislabeling as a continuous concern in the seafood

19 industry, especially with higher-valued species. Furthermore, the lack of COOL compliance

20 among retailers is concerning and suggests a need for increased focus on these regulations.

22 Keywords: acceptable market name, country-of-origin labeling, mislabeling, seafood fraud,

23 species identification 


\section{Introduction}

Seafood is a valuable protein source worldwide, with global per capita seafood consumption at over $20 \mathrm{~kg}$ per year (FAO, 2018). In the U.S., an estimated $7.3 \mathrm{~kg}$ of fish and shellfish were consumed per person in 2017, an increase of $0.5 \mathrm{~kg}$ from the previous year (NOAA, 2015). The top commercial fish consumed in the U.S. are salmon, tuna, tilapia, pollock,

29 Pangasius, cod, and catfish (Delaware SeaGrant, 2018). Many fish fillets are similar in appearance yet have different market values, leading to the potential for species to be substituted

31 for the purpose of economic gain (Hellberg \& Morrissey, 2011). In addition to economic

32 deception, species mislabeling can lead to health hazards, such as exposure to toxins like 33 gempylotoxin and tetrodotoxin (Unicomb, Kirk, Yohannes, Dalton, \& Halliday, 2002; Yancy et

34 al., 2008). Mislabeling can also interfere with religious practices when kosher fish are substituted 35 with non-kosher fish, and undermine the effectiveness of certification programs focused on 36 reducing consumer demand for unsustainable fisheries (Willette et al. 2017). In the U.S., intentional mislabeling of food is prohibited under 21 U.S.C. 343:

38 Misbranded food. In order to avoid misleading consumers, the U.S. Food and Drug

39 Administration (FDA) recommends that fish should be labeled using an acceptable market name 40 provided in The Seafood List; however, numerous studies have reported seafood species 41 substitution and mislabeling on the U.S. marketplace (Bosko, Foley, \& Hellberg, 2018; Cline, 42 2012; FDA, 2018a; Khaksar et al., 2015; Mitchell \& Hellberg, 2016; Shokralla, Hellberg, Handy, 43 King, \& Hajibabaei, 2015; Wang \& Hsieh, 2016; Warner, Timme, Lowell, \& Hirshfield, 2013; 44 Willette et al., 2017; Wong \& Hanner, 2008). A series of market surveys conducted across the 45 U.S. revealed 18\% species mislabeling from 731 fish collected from grocery stores, with snapper 46 and grouper having the highest rates of mislabeling (Warner et al., 2013). Within California, 
47 studies have reported mislabeling rates of 2.2\% (San Francisco) to 42\% (Los Angeles) for fish

48 samples collected at grocery stores (Bosko et al., 2018; Khaksar et al., 2015; Warner, Timme,

49 Lowell, \& Hirshfield, 2012; Willette et al., 2017). Some of the most commonly mislabeled fish

50 detected in these studies were advertised as red snapper, yellowtail, yellowfin tuna, and salmon.

51 DNA-based methods are widely used for fish species authentication due to their accuracy

52 and increased accessibility (Naaum \& Hanner, 2016). DNA barcoding is a sequencing-based

53 method that is commonly used for fish species identification (Naaum \& Hanner, 2016). This

54 method is based on genetic variation within a standardized region, which in animals is typically a

$55 \sim 650$ base-pair (bp) fragment of the gene coding for cytochrome $c$ oxidase subunit I (COI)

56 (Hebert, Ratnasingham, \& deWaard, 2003). COI generally exhibits high variability between

57 species and conservation within species (Stern, Castro Nallar, Rathod, \& Crandall, 2017). DNA

58 barcoding has been adopted by the U.S. FDA for regulatory identification of fish species (Handy

59 et al., 2011), and been successfully used to identify fish species in numerous studies (reviewed in

60 Hellberg, Pollack, \& Hanner, 2016). DNA barcode data for fish species is available through

61 Fish-Barcode of Life (Fish-BOL), a global initiative to assemble a standardized reference

62 sequence library for all fish species, and FDA's Regulatory Fish Encyclopedia (BOLDSystems,

63 2019; FDA, 2018b).

64 In addition to accurate species labeling, certain fresh and frozen seafood products (described

65 below) must also follow Country of Origin labeling (COOL) regulations (Country of Origin

66 Labeling for Fish and Shellfish, 7 C.F.R. $\S 60,2009)$. COOL is a labeling law that requires

67 retailers under the Perishable Agriculture Commodities Act (PACA) to provide consumers with

68 information on the geographic origin and production method for fresh and frozen fish fillets,

69 steaks, and nuggets that have not undergone transformation or further processing (USDA, 2017a, 
70 2017b). The information must be legible and displayed in a conspicuous location, such as on a

71 placard sign, label, sticker, band, or twist tie. Abbreviations for countries are not acceptable

72 unless the codes cannot be mistaken for any other country or are common (USDA, 2017b).

73 Furthermore, COOL regulations prohibit phrases such as "or," "may contain," and "and/or" to

74 prevent confusion to consumers (USDA, 2017b). In addition to these regulations, foreign articles

75 imported into the United States must be labeled with the correct country of origin according to

7619 C.F.R. $\S 134.11$, unless exempt by law.

About $90 \%$ of the seafood consumed in the U.S. is imported (NOAA, 2017); however,

78 only a couple of peer-reviewed studies have investigated COOL compliance among retailers.

79 One study conducted in Baltimore, $\mathrm{MD}$, reported that $3.8 \%$ of the 628 fresh/frozen seafood

80 products examined from 14 stores were not COOL compliant (Lagasse, Love, \& Smith, 2014).

81 Among the products, $1.1 \%$ did not state a country of origin and $2.7 \%$ did not state a procurement

82 method (Lagasse et al., 2014). Another study surveyed catfish samples in Southern California

83 and reported that $59 \%$ of the 32 catfish products collected from 31 grocery stores were not

84 compliant with COOL regulations (Bosko et al., 2018). Among the 32 samples, $50 \%$ had

85 incomplete or absent production method information and $31 \%$ were non-compliant for country-

86 of-origin information. The higher levels of non-compliance observed by Bosko et al. (2018) may

87 have been due to a number of factors, including differences in the number of retail locations

88 visited, the fish types targeted, and the geographic locations for each study.

89 While numerous studies have been carried out on fish species substitution in the

90 commercial marketplace, there is a lack of research that considers additional types of fish

91 mislabeling. Therefore, the objective of this study was to examine fish fillets sold in Southern 
92 California grocery stores for species authentication, use of acceptable market names, and COOL

93 compliance.

\section{2. Materials and Methods}

95 2.1 Sample collection

A total of 120 fresh or thawed (previously frozen) fish fillets were collected from 30

97 grocery stores in Orange County, CA. Sixteen categories of fish were targeted based on their

98 availability at grocery stores: bass, catfish, cod, halibut, mahi-mahi, Pangasius, rockfish,

99 rockfish/snapper, salmon, snapper, sole, swordfish, tilapia, trout, tuna and yellowtail. The

100 "rockfish/snapper" category included samples that were advertised as both snapper and rockfish.

101 A maximum of 10 fish fillets were purchased per category with no more than two fish fillets

102 from the same category purchased from the same retailer. All fish purchased for the study were

103 from grocery stores licensed under PACA according to USDA's PACA Search Engine

104 (https://apps.ams.usda.gov/pacasearch/). COOL information, species labeling, and price were

105 photographed at the time of purchase (e.g., on placards, stickers, signs, labels, etc.) with the

106 exact wording recorded. Figure 1 displays examples of COOL compliant labels collected in the

107 study. Pictures were taken of the sign of the fish being sold, location of the COOL information,

108 front/back of the packaged fish, receipts, and the unpackaged fish fillet. COOL compliance was

109 assessed by examining the packaging of each product as well as any relevant information

110 provided at the point of sale. In cases where the COOL information provided was questionable

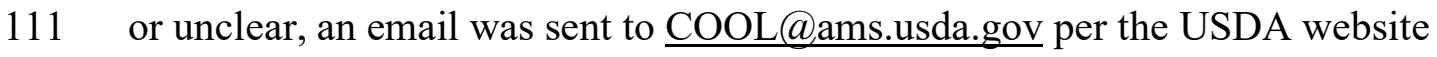

112 (https://www.ams.usda.gov/rules-regulations/cool/questions-answers-consumers) to determine

113 whether the product was considered compliant. Following collection, fish samples were

114 transported to the laboratory in a cooler with ice packs and stored at $4^{\circ} \mathrm{C}$. All fish were processed 
115 within $24 \mathrm{~h}$ of arrival to the laboratory. A subsample of the interior of the fish ( $10 \mathrm{mg})$ was

116 aseptically removed and placed in a sterile $1.5 \mathrm{~mL}$ microcentrifuge tube for immediate DNA

117 extraction. The remaining sample was preserved at $-80^{\circ} \mathrm{C}$.

$118 \quad 2.2$ DNA extraction and quantification

119 DNA extraction was performed on each sample using the DNeasy Blood and Tissue Kit

120 (Qiagen, Hilden, Germany), Spin-Column protocol with modifications described in Handy et al.

121 (2011). Lysis was carried out at $56^{\circ} \mathrm{C}$ with shaking at $300 \mathrm{rpm}$ in an Eppendorf ThermoMixer C

122 (Hamburg, Germany) for $2 \mathrm{~h}$. DNA was eluted in $100 \mu \mathrm{L}$ of preheated AE buffer $\left(37^{\circ} \mathrm{C}\right)$. The

123 concentration of each DNA extract was measured using a Biophotometer Plus (Eppendorf). Any

124 sample with a concentration $>30 \mathrm{ng} / \mu \mathrm{L}$ was diluted with AE buffer to achieve a concentration

$125 \leq 30 \mathrm{ng} / \mu \mathrm{L}$, as described in Moore et al. (2012). Extracted DNA was stored at $4^{\circ} \mathrm{C}$ until use in

126 PCR. Each set of DNA extractions also included a negative control in the form of a reagent blank

127 without fish tissue.

$128 \quad 2.3$ PCR and DNA sequencing

129 All samples underwent full barcoding (655 bp) of the COI gene as described in Moore et

130 al. (2012), except that the reaction volumes were doubled in order to improve workflow. Each

131 reaction tube contained $12.5 \mu \mathrm{L} 10 \%$ trehalose, $8.0 \mu \mathrm{L}$ molecular grade $\mathrm{H}_{2} \mathrm{O}, 0.5$ OmniMix ${ }^{\circledR} \mathrm{HS}$

132 Lyophilized PCR Master Mix bead (Cepheid, Sunnyvale, CA), $0.25 \mu \mathrm{L}$ of each $10 \mu \mathrm{M}$ COI full

133 barcode primer (Table 1), and $2.0 \mu \mathrm{L}$ of DNA template $(\leq 30 \mathrm{ng} / \mu \mathrm{L})$. Cycling conditions for full

134 barcoding were $94^{\circ} \mathrm{C}$ for $2 \mathrm{~min}$; followed by 35 cycles of $94^{\circ} \mathrm{C}$ for $30 \mathrm{~s}, 55^{\circ} \mathrm{C}$ for $40 \mathrm{~s}$, and $72{ }^{\circ} \mathrm{C}$

135 for $1 \mathrm{~min}$; with a final extension of $72^{\circ} \mathrm{C}$ for $10 \mathrm{~min}$. All thermal cycling reactions were carried

136 out using an Eppendorf Mastercycler nexus gradient. 
138 repeat PCR using the full barcoding conditions described above, as well as mini barcoding using 139 the Mini_SH-E primer set described in Shokralla et al. (2015). For mini-barcoding, each reaction 140 tube contained 22.0 $\mu \mathrm{L}$ molecular grade $\mathrm{H}_{2} \mathrm{O}, 0.5$ OmniMix ${ }^{\circledR}$ HS Lyophilized PCR Master Mix 141 bead, $0.50 \mu \mathrm{L}$ of each $10 \mu \mathrm{M}$ COI mini-barcode SH-E primer (Table 1), and $2.0 \mu \mathrm{L}$ of DNA 142 template. Cycling conditions were $95^{\circ} \mathrm{C}$ for $5 \mathrm{~min}$; followed by 35 cycles of $94^{\circ} \mathrm{C}$ for $40 \mathrm{~s}, 46^{\circ} \mathrm{C}$ 143 for $1 \mathrm{~min}$, and $72^{\circ} \mathrm{C}$ for $30 \mathrm{~s}$; with a final extension of $72^{\circ} \mathrm{C}$ for $5 \mathrm{~min}$. In order to differentiate 144 closely related tuna species, all tuna samples were also tested using a mini-barcode primer set 145 targeting the control region (CR), as described in Mitchell and Hellberg (2016). Each reaction 146 tube contained $20.5 \mu \mathrm{L}$ molecular grade $\mathrm{H}_{2} \mathrm{O}, 0.5$ OmniMix ${ }^{\circledR}$ HS Lyophilized PCR Master Mix 147 bead, $0.50 \mu \mathrm{L}$ of each $10 \mu \mathrm{M} \mathrm{CR}$ mini-barcode primer (Table 1), and $3.0 \mu \mathrm{L}$ of DNA template. 148 Cycling conditions were $94^{\circ} \mathrm{C}$ for $2 \mathrm{~min}$; followed by 35 cycles of $94^{\circ} \mathrm{C}$ for $30 \mathrm{~s}, 49^{\circ} \mathrm{C}$ for $40 \mathrm{~s}$, 149 and $72{ }^{\circ} \mathrm{C}$ for $1 \mathrm{~min}$; with a final extension of $72{ }^{\circ} \mathrm{C}$ for $10 \mathrm{~min}$. PCR products were confirmed using pre-cast 2\% agarose E-Gels (Invitrogen, Carlsbad, $151 \mathrm{CA}$ ) run for 15 min on an E-Gel iBase (Invitrogen). Each well was loaded with $4 \mu \mathrm{L}$ PCR 152 product and $16 \mu \mathrm{L}$ sterile deionized water. Image results were captured using FOTO/Analyst 153 Express (Fotodyne, Hartland, WI) and Transilluminator FBDLT-88 (Fisher Scientific, Waltham, 154 MA) and visualized with FOTO/Analyst PCImage (version 5.0.0.0, FOTODYNE). PCR 155 products were purified using ExoSAP-IT (Affymetrix, Santa Clara, CA) according to the 156 manufacturer's instructions. Next, the samples were sequenced bidirectionally with M13 primers 157 at the GenScript facility (Piscataway, NJ). Sequencing was carried out using the BigDye 158 Terminator v3.1 Cycle Sequencing Kit (Applied Biosystems, Foster City, CA) and a 3730x1 159 Genetic Analyzer (Applied Biosystems). 
161 Raw sequence data was assembled using Geneious R7 (Biomatters, Ltd., Auckland, New

162 Zealand) and trimmed to the target regions for the $655 \mathrm{bp}$ full-length COI barcode, $226 \mathrm{bp}$ COI

163 mini-barcode, or 236 bp CR mini-barcode. Full-length COI barcodes were considered successful

164 if they passed the QC parameters described by Handy et al. (2011): bidirectional sequences with

$165 \geq 500$ bp and $<2 \%$ ambiguities or single reads with $\geq 500$ bp and $\geq 98 \%$ high quality bases. COI

166 and CR mini barcodes were considered successful if they passed the QC parameters utilized by

167 Pollack et al. (2018): bidirectional sequences with $\geq 76 \%$ of the target length and $<2 \%$

168 ambiguities or single reads with $\geq 76 \%$ of the target length and $\geq 98 \%$ high quality bases. The

169 full and mini-barcode COI sequences were queried against the Species Level Barcode Records in

170 the Barcode of Life Database (BOLD) and CR mini-barcodes were queried against GenBank

171 using the Basic Local Alignment Search Tool (BLAST). Common names and acceptable market

172 names for each identified species were determined using The Seafood List (FDA, 2018a). For

173 species not listed in The Seafood List, FishBase was used to determine the common names

174 (FishBase, 2018).

\section{3. Results and Discussion}

$176 \quad 3.1$ DNA barcoding results

177 All of the 120 fish fillets collected were sequenced with at least one of the COI barcoding 178 methods described above and all samples had at least one top species match in BOLD with $>99 \%$ 179 genetic similarity (Table 2$)$. The majority of samples $(n=116)$ were sequenced using the COI

180 full barcode primer set and the remaining four samples were sequenced with the COI mini-

181 barcode primer set. The four samples that were only successful with mini-barcoding were

182 identified as Atlantic salmon (Salmo salar; $\mathrm{n}=2$ ), Patagonian toothfish (Dissostichus 
183 eleginoides; $\mathrm{n}=1$ ), and Antarctic toothfish (Dissostichus mawsoni; $\mathrm{n}=1$ ). Among the 120 fillets

184 tested, 82 were identified to the species level (i.e., showed a top match to a single species in

185 BOLD) using COI full or mini-barcoding. This included all samples labeled as bass, catfish,

186 salmon, snapper, sole, swordfish, trout, yellowtail and most samples labeled as cod, halibut,

187 mahi-mahi, rockfish (Table 2).

188 Among the 38 samples that were not identified to the species level with COI full or mini-

189 barcoding, 23 were identified to the genus level (i.e., showed a top match to multiple species

190 from the same genus). These included the majority of the tilapia and tuna samples and a few

191 samples of halibut, mahi-mahi, and rockfish (Table 2). Most of the tilapia samples had top

192 matches to Oreochromis hybrids and therefore could not be identified at the species level. Many

193 species of tuna are closely related and previous studies have also reported an inability to

194 differentiate species based on COI DNA barcoding (Pollack et al., 2018; Shokralla et al., 2015).

195 These samples underwent further analysis with the CR mini-barcodes to verify species. All 10

196 tuna samples were successfully sequenced using the CR mini-barcode primer set and identified

197 as yellowfin tuna (Thunnus albacares; $\mathrm{n}=5$ ), Pacific bluefin tuna (Thunnus orientalis; $\mathrm{n}=2$ ),

198 albacore tuna (Thunnus alalunga; $\mathrm{n}=1$ ), southern bluefin tuna (Thunnus maccoyii; $\mathrm{n}=1$ ), and

199 Thunnus spp. $(\mathrm{n}=1)$. The CR mini-barcodes showed 100\% query coverage and $95-100 \%$

200 genetic similarity to the top species matches in GenBank, consistent with the results of Mitchell 201 and Hellberg (2016).

202 Samples with top matches from multiple genera were primarily from the Pangasius $(\mathrm{n}=$ 203 9) and cod $(\mathrm{n}=5)$ categories (Table 2). The Pangasius samples showed top matches to records 204 from the genera Pangasianodon and Pangasius, which are both within the Pangasiidae family, 
205 while the cod samples showed equivalent matches to records from the genera Gadus and

206 Boreogadus, which are both within the Gadidae family.

2073.2 Species substitution

208 Species substitution was detected in 16 of the 120 fish fillets (13.3\%) examined in this

209 study (Table 3). Among the 16 fish categories tested, 7 had at least one sample with species

210 substitution. The highest rate of substitution was observed for the snapper fillets (3/3), followed

211 by yellowtail (2/4), halibut (4/10), $\operatorname{cod}(3 / 10)$, and bass (2/7). The Pangasius and tuna categories

212 each had one sample with species substitution. Categories with no species substitution detected

213 included: catfish, mahi-mahi, rockfish, rockfish/snapper, salmon, sole, swordfish, tilapia, and

214 trout. Similar to the results of the current study, previous market surveys in the U.S. also found

215 relatively high rates of mislabeling among snapper, halibut, and cod, and yellowtail products

216 (Hu, Huang, Hanner, Levin, \& Lu, 2018; Khaksar et al., 2015; Shehata, Naaum, Garduno, \&

217 Hanner, 2018; Warner et al., 2013; Willette et al., 2017). Of the 30 stores sampled in the current

218 study, 13 had at least one incidence of species substitution. The three most expensive categories

219 of fish had relatively high rates of species substitution: snapper, bass, and halibut were on

220 average the highest-priced fish categories at US $\$ 99.93 / \mathrm{kg}, \$ 88.18 / \mathrm{kg}$, and $\$ 49.01 / \mathrm{kg}$,

221 respectively.

222 According to The Seafood List, the name "red snapper" is only acceptable for Lutjanus

223 campechanus (FDA, 2018a). However, none of the fillets advertised as "red snapper" in this

224 study were identified as L. campechanus (Tables 2-3). As shown in Table 3, the three substituted

225 "red snapper" fillets were identified as blackspotted rockfish [(Sebastes melanostictus) $(\mathrm{n}=1)]$

226 and madai [(Pagrus major) $(\mathrm{n}=2)]$. According to the California Code of Regulations (14 CCR

$227 \S 103)$, "Pacific red snapper" can be used as a common name for certain species of rockfish 
228 including widow rockfish (Sebastes entomelas) and vermilion rockfish (Sebastes miniatus).

229 However, none of the samples collected in this study were specifically labeled as "Pacific red

230 snapper." The two "red snapper" samples identified as madai were sold as "fresh red snapper"

231 farmed in Japan $(\$ 132.28 / \mathrm{kg})$ and "premium red snapper" wild caught in Japan $(\$ 154.32 / \mathrm{kg})$

232 (Fig. 1a). Madai is a type of sea bream that is recognized as genuine snapper in sushi culture and

233 this may have led to confusion over the acceptable market name (Hu et al., 2018). Consistent

234 with the results of the current study, Khaksar et al. (2015) also reported 100\% of "red snapper"

235 samples to be mislabeled, with 8 of the 16 samples identified as madai and the other 8 identified

236 as tilapia. Similarly, Warner et al. (2013) reported a high rate of red snapper mislabeling (113 of

237120 samples), with samples identified as various species, including madai ( $\mathrm{n}=5)$ and numerous

238 types of rockfish $(\mathrm{n}=30)$. These results, along with those of other studies (Hsieh, Woodward, \&

239 Blanco, 1995; Hu et al., 2018; Marko et al., 2004; Shehata et al., 2018; Willette et al., 2017),

240 indicate that red snapper substitution continues to be a major problem.

241 According to 21 CFR $\S 102.57$, the term "halibut" can only be associated with Atlantic

242 halibut (Hippoglossus hippoglossus) or Pacific halibut (Hippoglossus stenolepis). However, four

243 of the ten fillets in this study advertised as "halibut" or "Pacific halibut" were identified as

244 California flounder (Paralichthys californicus) (Table 3). Interestingly, "California halibut" is

245 listed as a vernacular name for California flounder on The Seafood List and it is the name used to

246 refer to P. californicus in the California Fish and Game Code (e.g., §8391). However, as stated

247 by the FDA, vernacular names are generally not acceptable market names and use of these names

248 may lead to misbranding. Consistent with these results, Warner et al. (2013) also detected

249 California flounder labeled as "Pacific halibut" in four samples purchased in Northern 
250 California. Willette et al. (2017) found that $89 \%$ of marketed halibut was actually flounder

251 (Paralichthys spp.), although none were identified as California flounder.

252 Among the cod samples, two were advertised as Pacific cod (Gadus microcephalus) but

253 identified as Atlantic cod (Gadus morhua) and one was advertised as rock cod (Lotella rhacina

254 or Pseudophycis barbata) but identified as redbanded rockfish (Sebastes babcocki) (Table 3).

255 Mislabeling Atlantic cod as Pacific cod could undermine conservation efforts at the retail level, 256 as Atlantic cod is considered vulnerable by the International Union for Conservation of Nature 257 (IUCN) Red List (IUCN, 2019). According to NOAA Fisheries, Atlantic cod populations are 258 below target levels; however, U.S. wild-caught Atlantic cod is being sustainably managed with 259 limited harvesting and rebuilding plans in place (NOAA, 2019). Of note, one of the Atlantic cod 260 samples (P031) listed the U.S. as the country of origin, while the other sample (P001) listed 261 Iceland. Similar to the results of this study, Warner et al. (2013) reported a mislabeling rate of $26228 \%$ for cod species, including Atlantic cod mislabeled as Pacific cod and redbanded rockfish 263 mislabeled as rock cod, while Shehata et al. (2018) also found Atlantic cod mislabeled as Pacific 264 cod.

265 The bass category included one fillet labeled as "seabass (Patagonian toothfish)" and six

266 fillets labeled as "Chilean seabass." As shown in Table 3, the sample labeled as "seabass

267 (Patagonian toothfish)" was determined to be substituted because Patagonian toothfish

268 (Dissostichus eleginoides) is a different species than Antarctic toothfish (Dissostichus mawsoni).

269 Within the "Chilean seabass" samples, one was identified as swordfish (Xiphias gladius). The

270 substitution of Chilean seabass with swordfish could have been intentionally carried out for

271 economic gain, as the average price of swordfish in this study was US $\$ 28.55 / \mathrm{kg}$ compared to

272 US $\$ 69.31 / \mathrm{kg}$ for samples labeled as Chilean seabass. The substitution is also a health concern as 
273 swordfish is not recommended for certain populations (i.e. pregnant women, young children) due

274 to mercury levels, while Chilean sea bass is listed as a "good choice" (FDA, 2019).

275 The Pangasius, tuna, and yellowtail categories each had one sample found to be

276 substituted (Table 3). Interestingly, a sample labeled as "swai" was identified as blue-spotted

277 stingray (Neotrygon kuhlii). Economically motivated adulteration in this case seems unlikely, as

278 the average price of the Pangasius samples in this study was relatively low (US $\$ 9.91 / \mathrm{kg}$, range

$279 \$ 8.79-13.21 / \mathrm{kg})$. The substituted tuna sample was labeled as "yellowfin tuna" but identified as

280 southern bluefin tuna. Southern bluefin tuna is considered critically endangered according to the

281 IUCN Red List (Collette, Chang, et al., 2011), while yellowfin tuna is considered near threatened

282 (Collette, Acero, et al., 2011). The country-of-origin information for this tuna sample was

283 conflicting, with "Indonesia" listed on the placard and "Fiji" on the label. Economically

284 motivated adulteration seems unlikely, as this sample was marketed at US $\$ 22.05 / \mathrm{kg}$ as

285 compared to US $\$ 59.52$ for the other yellowfin tuna sample in this study. Lastly, two samples

286 (P035 and P104) advertised as "yellowtail" were identified as buri (Seriola quinqueradiata).

287 Although buri shares the same genus as yellowtail (Seriola lalandi), they are two distinct species.

288 In addition, the country of origin and production method were both missing for P035 (Fig. 2d) .

289 Buri is a common substitute for yellowtail, as Warner et al. (2013) previously identified 24 out of

29026 "yellowtail" samples as buri. The authors indicated that the deception was likely

291 unintentional, as buri is often called "yellowtail" at sushi restaurants. Interestingly, the average

292 cost of actual yellowtail samples in the current study was US $\$ 7.67 / \mathrm{kg}$, while the average cost of

293 the "yellowtail" samples identified as buri was much higher, at US $\$ 42.99 / \mathrm{kg}$.

2943.3 Acceptable market name 
The use of an acceptable market name to identify seafood sold in interstate commerce is

296 important in order to ensure proper labeling and avoid misleading consumers (FDA, 2018a).

297 Among the 120 samples, 11 samples from 10 stores were mislabeled due to the use of an

298 unacceptable market name (Table 4). When samples with species substitution and unacceptable

299 market names were combined, the overall rate of mislabeling was $22.5 \%(27 / 120)$. The category

300 with the greatest number of unacceptable market names was salmon (5/10), followed by

301 rockfish/snapper (2/2), cod (2/10), and Pangasius (2/10). The two samples of rockfish/snapper

302 were found to have unacceptable market names because of conflicting labeling information: one

303 sample was labeled as "Fresh Pacific Snapper Filet" on the placard and "Pacific Rockfish Fillet

304 Wild-Fresh" on the label, while the other was labeled as "Fresh Rockfish Red Snapper" on the

305 placard and "Rock Fish Fillets" on the label. However, "Pacific snapper" is only acceptable for

306 Lutjanus peru and, as previously mentioned, "red snapper" is only acceptable for Lutjanus

307 campechanus. In the state of California, certain rockfish species may be labeled as "Pacific Red

308 Snapper" according to the California Code of Regulations $§ 103$. However, this name was not

309 used for any of the rockfish samples collected.

310 The five mislabeled salmon samples were labeled as "salmon" and identified as "Atlantic

311 salmon." Although these fillets were labeled with the correct category of fish, none of them used

312 the complete name of "Atlantic salmon" as specified by The Seafood List. Another mislabeling

313 trend was the use of multiple names on the same product that refer to different species. For

314 example, one of the mislabeled Pangasius samples was marketed as both "swai" and "basa" and

315 another was marketed as "red fish basa." "Swai" and "basa" refer to two different species as do

316 "red fish" and "basa." "Redfish" appears as a vernacular name for a number of species in The

317 Seafood List, including sea bass, ocean perch, and sockeye salmon. In another case, a fillet 
318 identified as sablefish (Anoplopoma fimbria) was labeled with the vernacular name of "black

319 cod." The other mislabeled cod sample was advertised as "lind cod." Lind cod is not listed in The

320 Seafood List and it may be a possible misspelling of ling cod (Molva movla). However, the

321 sample had equivalent species matches to Pacific cod (Gadus macrocephalus)/Arctic cod

322 (Boreogadus saida)/Greenland cod (Gadus ogac), none of which are associated with an

323 acceptable market name of "ling cod."

3243.4 COOL compliance

325 To comply with COOL regulations, the country of origin and production method must be

326 stated legibly in a conspicuous location at the point of sale. Examples of COOL-compliant

327 samples collected in this study are shown in Figure 1. COOL noncompliance was observed for

32828 of the 120 samples (23.3\%) in this study (Table 5). A greater number of samples were not

329 compliant in their country-of-origin statement $(n=15)$ compared to samples that were

330 noncompliant for production method $(\mathrm{n}=9)$. Four additional samples were noncompliant for

331 both country of origin and production method information. Only four of the fish categories (i.e.,

332 cod, rockfish, rockfish/snapper, and trout) had samples that were $100 \%$ COOL compliant. Each

333 of the remaining categories had at least one incidence of COOL noncompliance, with tuna

334 having the highest number of non-compliant samples $(n=5)$. At least one sample from 15 of the

33530 stores $(50.0 \%)$ sampled had an incidence of COOL noncompliance.

336 Samples were considered not compliant in their country-of-origin statement for several

337 reasons: ten samples were missing a country of origin or stated "Other" as the country of origin;

338 six listed multiple countries; and three did not use a valid country name. The samples with

339 multiple countries had contradictory information on the label as compared to the placard. For

340 example, one sample was a "red snapper" fillet (P019) that listed Canada on the placard and 
341 Brazil on the label. Of note, this sample was substituted with blackspotted rockfish and also

342 contained contradictory production method information, declaring "Farm Raised" on the placard

343 and "Wild" on the label. Another sample with contradictory information was a catfish fillet

344 (P018) that declared "Product of China" on the placard and "Product of Ecuador" on the label.

345 Interestingly, the label for this sample appeared have been intended for use with a shrimp

346 product, as it read "26-30 Raw Headless Shri Previously Frozen Farmed." One of the samples

347 (P032) with an invalid country name stated "Product of Tahiti" instead of the country name of

348 French Polynesia. The other two samples with invalid country names were bass fillets that listed

349 "Korea" (P029) or "Korean" (P105) (Fig. 2a) as the country of origin. Because South Korea and

350 North Korea are two separate countries, simply stating "Korea" is considered insufficient (K.

351 Becker, personal communication, October 10, 2018). Of note, the sample that listed "Korea" as

352 the country of origin was also found to be mislabeled on the basis of species: it was advertised as

353 "seabass (Patagonian toothfish)" but identified as Antarctic toothfish.

354 Among the 13 samples that were noncompliant with regards to declaring the production

355 method, ten samples did not state the production method, two had unclear wording, and one had

356 contradictory information. The two samples with unclear wording were a mahi-mahi fillet with

357 the declaration "Born, Raised, Harvested China" (Fig. 2b) and a tilapia fillet with the declaration

358 "BRN,RAISD\&HARVST CHINA." These statements reflect the legal designations required for

359 muscle cuts of meat from animals slaughtered in the U.S. (7 CFR $\$ 65.300 \mathrm{~d}$ ) and they are not

360 acceptable for conveying production method for fish and shellfish (K. Becker, personal

361 communication, April 9, 2019).

362 Interestingly, two samples with COOL information listed a country of origin or

363 production method that was not consistent with the labeled species. In one case, a sample labeled 
364 as "Wild Caught Pacific Cod" (P001) listed Iceland as the country of origin. While Pacific cod

365 can be found in the waters off of western Greenland, its geographic range does not extend to

366 Iceland (Luna \& Capuli, 2019). The sample was identified to be Atlantic cod, which is a major

367 fishery in Iceland (FAO, 2010). Another sample was labeled as farmed mahi-mahi (no country of

368 origin stated); however, the Food and Agriculture Organization of the United Nations (FAO)

369 does not have production statistics for farmed mahi-mahi (FAO, 2018).

370 The rate of COOL noncompliance in this study (23.3\%) was mid-range compared to

371 previous studies. Lagasse et al. (2014) found only 3.8\% COOL noncompliance from the 628

372 seafood products examined in their study. However, their samples were collected from only eight

373 retail outlets compared to 30 grocery stores in this study and included both fresh and frozen

374 products. COOL compliance surveillance conducted by the Agricultural Marketing Service

375 (AMS) in 2016 revealed 10\% COOL noncompliance among 79,928 fish and shellfish products

376 from over 3,000 retail store facilities across the United States (K. Becker, personal

377 communication, June 21, 2017). On the other hand, Bosko et al. (2018) reported 59\% COOL

378 noncompliance among 32 fresh/frozen catfish samples collected from grocery stores. In

379 comparison, the current study found a lower rate of noncompliance (33.3\%) among the 10 catfish

380 products analyzed. While relatively high rates of COOL noncompliance have been observed in

381 studies specific to Southern California, these differences may be due to variation in sampling

382 design rather than regional differences in COOL compliance. A more extensive study focused on

383 comparing COOL compliance in multiple geographic regions should be carried out in order to

384 investigate these differences further.

3853.5 Overall mislabeling 
When considering all forms of mislabeling investigated in this study (i.e., species

387 substitution, unacceptable market name, and/or COOL noncompliance), 47 of the 120 samples

388 (39.2\%) had at least one labeling error. Eight samples exhibited COOL noncompliance combined

389 with species mislabeling (i.e., species substitution or unacceptable market name). Among these

390 samples, there were seven instances of species substitution and one use of an unacceptable

391 market name. These samples were from a range of categories, including bass, halibut, Pangasius,

392 salmon, snapper, tuna, and yellowtail. Among the 30 stores sampled, 24 stores $(80.0 \%)$ had at

393 least one incidence of species mislabeling or COOL noncompliance.

\section{4. Conclusions}

This study revealed species mislabeling and COOL noncompliance across various fish

396 categories in grocery stores in Southern California. The results of the current study combined

397 with previous research indicate that mislabeling of fish species continues to be a problem.

398 Several instances of higher-value species substituted with species of lesser value were detected

399 in this study, such as halibut substituted with California flounder. However, many instances of

400 species mislabeling appeared to be a result of confusion in naming fish associated with sushi

401 culture (e.g., use of the term "madai" for red snapper) or a misunderstanding of California state

402 and federal labeling laws (e.g. use of "Pacific halibut" for California flounder), rather than

403 carried out for economic gain. Numerous errors associated with COOL compliance were also

404 observed, including lack of a country-of-origin statement, lack of production method, and

405 confusing or contradictory wording. Non-compliant samples may be due to a lack of consistency

406 at certain grocery stores, as some samples displayed contradictory information between the

407 placard and the label and others used wording meant for cuts of meat instead of fish (e.g. "born,

408 raised, \& harvested"). Accurate and compliant labeling is an important aspect in determining 
409 appropriate food safety measures, promoting seafood conservation, and allowing consumers to

410 make informed choices associated with seafood consumption. As a labeling law, COOL provides

411 transparency in the supply chain to consumers. The high number of stores $(80.0 \%)$ and fish

412 products $(39.2 \%)$ that had at least one mislabeling error indicates an area of concern and a need

413 for further monitoring as well as greater enforcement of regulations.

\section{Acknowledgements}

415 This work was supported in part by a grant from the National Science Foundation,

416 Division of Earth Sciences, NSF-EAR \#1757991. Additional funding support was received from

417 Chapman University, Schmid College of Science and Technology. We would like to thank Dr.

418 Kenneth Becker from U.S. Department of Agriculture and Spring Randolph from U.S. Food and

419 Drug Administration for their help in providing resources and clarification related to regulatory 420 questions.

\section{$421 \quad$ References}

422 Bosko, S., Foley, D., \& Hellberg, R. (2018). Species substitution and country of origin

423 labeling of catfish products on the U.S. commercial market. Aquaculture, 495, 715-720.

424 Cline, E. (2012). Marketplace substitution of Atlantic salmon for Pacific salmon in

425 Washington State detected by DNA barcoding. Food Research International, 45, 388-

426393.

427 Cohen, N. J., Deeds, J. R., Wong, E. S., Hanner, R. H., Yancy, H. F., White, K. D., . . Gerber,

428 S. I. (2009). Public health response to puffer fish (Tetrodotoxin) poisoning from

429 mislabeled product. Journal of Food Protection, 72(4), 810-817.

430 Collette, B., Acero, A., Amorim, A. F., Boustany, A., Canales Ramirez, C., Cardenas, G., 

... Yanez, E. (2011). Thunnus albacares. The IUCN Red List of Threatened Species. http://dx.doi.org/10.2305/IUCN.UK.2011-2.RLTS.T21857A9327139.en Accessed 2 April 2019.

434 Collette, B., Chang, S.-K., Di Natale, A., Fox, W., Juan Jorda, M., Miyabe, N., .. . Wang, S. (2011). Thunnus maccoyii. The IUCN Red List of Threatened Species. http://dx.doi.org/10.2305/IUCN.UK.2011-2.RLTS.T21858A9328286.en Accessed 2

Delaware Sea Grant. (2018). Seafood Health Facts. www.seafoodhealthfacts.org April 2019.

FAO. (2010). Fishery and Aquaculture Country Profiles: The Republic of Iceland. http://www.fao.org/fishery/facp/ISL/en\#CountrySector-ProductionSector Accessed 3 July 2019.

443 FAO. (2018). The State of World Fisheries and Aquaculture. http://www.fao.org/3/I9540EN/i9540en.pdf Accessed 4 April 2019.

445 FDA. (2019). Advice about Eating Fish.

446 https://www.fda.gov/food/consumers/advice-about-eating-fish Accessed 17 July 2019.

448 FDA. (2018a). The Seafood List. https://www.accessdata.fda.gov/scripts/fdcc/index.cfm?set=seafoodlist Accessed 3 July 2019.

451 FDA. (2018b). Regulatory Fish Encyclopedia.

452 https://www.fda.gov/food/foodscienceresearch/rfe/ Accessed 3 July 2019.

453 FishBase. (2018). http://www.fishbase.org/search.php Accessed 3 July 2019. 
454 Handy, S. M., Deeds, J. R., Ivanova, N. V., Hebert, P. D. N., Hanner, R. H., Ormos, A., .

455

456

457

458

459

460

461

462

463

464

465

466

467

468

469

470

471

472

473

474

475

476

. Yancy, H. F. (2011). A single-laboratory validated method for the generation of DNA barcodes for the identification of fish for regulatory compliance. Journal of AOAC International, 94(1), 201-210.

Hebert, P. D. N., Ratnasingham, S., \& deWaard, J. R. (2003). Barcoding animal life: cytochrome c oxidase subunit 1 divergences among closely related species. Proceedings: Biological Sciences, 270, S96-S99.

Hebert, P. D. N., \& Ratnasingham, S. (2007). Barcoding BOLD: The Barcode of Life Data system (www.barcodinglife.org). Molecular Ecology Notes, 7(3), 355-364.

Hellberg, R., \& Morrissey, M. (2011). Advances in DNA-based techniques for the detection of seafood species substitution on the commercial market. Journal of Laboratory Automation, 16(4), 308-321.

Hellberg, R., Pollack, S., \& Hanner, R. (2016). Seafood species identification using DNA sequencing. In A. Naaum \& R. Hanner (Eds.), Seafood authenticity and traceability: A DNA-based perspective (pp. 113-127). San Diego: Elsevier.

Hsieh, Y-H. P., Woodward, B. B., \& Blanco, A. W. (1995). Species substitution of retail snapper fillets. Journal of Food Quality, 18, 131-140.

Hu, Y., Huang, S. Y., Hanner, R., Levin, J., \& Lu, X. (2018). Study of fish products in Metro Vancouver using DNA barcoding methods reveals fraudulent labeling. Food Control, 94, 38-47.

IUCN. (2019). The IUCN Red List of Threatened Species. https://www.iucn.org/resources/conservation-tools/iucn-red-list-threatened-species Accessed 3 July 2019. 
Khaksar, R., Carlson, T., Schaffner, D. W., Ghorashi, M., Best, D., Jandhyala, S., .. . Amini, S. (2015). Unmasking seafood mislabeling in US markets: DNA barcoding as a unique technology for food authentication and quality control. Food Control, 56, 71-76.

Lagasse, L. P., Love, D. C., \& Smith, K. C. (2014). Country-of-Origin labeling prior to and at the point of purchase: an exploration of the information environment in Baltimore City grocery stores. Ecology of Food and Nutrition, 53(1), 58-80.

Luna, S. M., \& Capuli, E. E. (2019). Gadus macrocephalus. https://www.fishbase.se/summary/Gadus-macrocephalus.html Accessed 4 April 2019.

Marko, P. B., Lee, S. C., Rice, A. M., Gramling, J. M., Fitzhenry, T. M., McAlister, J. S., ... Moran, A. L. (2004). Mislabeling of a depleted reef fish. Nature, 430, 309-310.

Mitchell, J. K., \& Hellberg, R. S. (2016). Use of the mitochondrial control region as a potential DNA mini-barcoding target for the identification of canned tuna species. Food Analytical Methods, 9(10), 2711-2720.

Moore, M. M., Handy, S. M., Haney, C. J., Pires, G. S., Perry, L. L., Deeds, J. R., \& Yancy, H. F. (2012). Updates to the FDA single laboratory validated method for DNA barcoding for the species identification of fish. FDA Laboratory Information Bulletin 4528.

Naaum, A., \& Hanner, R. (2016). An introduction to DNA-based tools for seafood identification. In A. Naaum \& R. Hanner (Eds.), Seafood authenticity and traceability: a DNA-based perspective (pp. 100-110). San Diego: Elsevier.

NOAA. (2017). Fisheries of the United States. https://www.fisheries.noaa.gov/resource/document/fisheries-united-states-2017-report Accessed 30 July 2019. 
NOAA. (2017). U.S. Aquaculture.

https://www.fisheries.noaa.gov/national/aquaculture/us-aquaculture Accessed 3 July 2019.

NOAA. (2019). Atlantic Cod. https://www.fisheries.noaa.gov/species/atlantic-cod Accessed 3 July 2019.

Pollack, S. J., Kawalek, M. D., Williams-Hill, D. M., \& Hellberg, R. S. (2018). Evaluation of DNA barcoding methodologies for the identification of fish species in cooked products. Food Control, 84, 297-304.

Shehata, H. R., Naaum, A. M., Garduno, R. A., \& Hanner, R. (2018). DNA barcoding as a regulatory tool for seafood authentication in Canada. Food Control, 92, 147-153.

Shokralla, S., Hellberg, R. S., Handy, S. M., King, I., \& Hajibabaei, M. (2015). A DNA mini-barcoding system for authentication of processed fish products. Scientific Reports, 5, Article number: 15894.

Stern, D. B., Castro Nallar, E., Rathod, J., \& Crandall, K. A. (2017). DNA barcoding analysis of seafood accuracy in Washington, D.C. restaurants. PeerJ, e3234.

Unicomb, L. E., Kirk, M., Yohannes, K., Dalton, C. B., \& Halliday, L. (2002). An outbreak of gastrointestinal illness associated with the consumption of escolar fish. Communicable Diseases Intelligence Quarterly Report, 26(3), 441-445.

USDA. (2017a). Country of Origin Labeling (COOL). https://www.ams.usda.gov/rules-regulations/cool Accessed 3 July 2019.

USDA. (2017b). Country of Origin Labeling (COOL) Frequently Asked Questions. https://www.ams.usda.gov/rules-regulations/cool/questions-answers-consumers Accessed 3 July 2019. 
523 Wang, D., \& Hsieh, Y.-H. P. (2016). The use of imported Pangasius fish in local

524 restaurants. Food Control, 65, 136-142.

525 Warner, K., Timme, W., Lowell, B., \& Hirshfield, M. (2012). Widespread Seafood Fraud

526 Found in Los Angeles. http://oceana.org/reports/widespread-seafood-fraud-found-los-

$527 \quad$ angeles Accessed 3 July 2019.

528 Warner, K., Timme, W., Lowell, B., \& Hirshfield, M. (2013). Oceana Study Reveals

529 Seafood Fraud Nationwide. http://oceana.org/reports/oceana-study-reveals-seafood-

$530 \quad$ fraud-nationwide Accessed 3 July 2019.

531 Willette, D., Simmonds, S., Cheng, S., Esteves, S., Kane, T., Nuetzel, H., . . Barber, P.

532 (2017). Using DNA barcoding to track seafood mislabeling in Los Angeles restaurants.

533 Conservation Biology, 31(5), 1076-1085.

534 Wong, E. H. K., \& Hanner, R. H. (2008). DNA barcoding detects market substitution in

$535 \quad$ North American seafood. Food Research International, 41(8), 828-837.

536 Yancy, H. F., Zemlak, T. S., Mason, J. A., Washington, J. D., Tenge, B. J., Nguyen, N. L. T., . . .

537 Moore, M. M. (2008). Potential use of DNA barcodes in regulatory science: applications

538 of the Regulatory Fish Encyclopedia. Journal of Food Protection, 71(1), 210-217.

539 
Table 1. Primer sets used in this study

\begin{tabular}{|c|c|c|c|c|c|}
\hline Primer set & Primer name & $\begin{array}{l}\text { Primer } \\
\text { direction }\end{array}$ & Primer sequence $\left(3^{\prime}-5^{\prime}\right)^{\mathrm{a}}$ & $\begin{array}{l}\text { Barcode } \\
\text { length }\end{array}$ & Reference \\
\hline \multirow[t]{2}{*}{$\begin{array}{l}\text { COI full } \\
\text { barcode }\end{array}$} & $\begin{array}{l}\text { FISHCOILB } \\
\text { C_ts }\end{array}$ & forward & $\begin{array}{l}\text { CACGACGTTGTAAAACGACTCAAC } \\
\text { YAATCAYAAAGATATYGGCAC }\end{array}$ & \multirow[t]{2}{*}{$655 \mathrm{bp}$} & \multirow{2}{*}{$\begin{array}{l}\text { Handy et al. } \\
\text { (2011); Moore } \\
\text { et al. (2012) }\end{array}$} \\
\hline & $\begin{array}{l}\text { FISHCOILB } \\
\text { C_ts }\end{array}$ & reverse & $\frac{\text { GGATAACAATTTCACACAGGACTTC }}{\text { YGGGTGRCCRAARAATCA }}$ & & \\
\hline \multirow{2}{*}{$\begin{array}{l}\text { COI mini- } \\
\text { barcode (SH- } \\
\text { E) }\end{array}$} & Mini_SH-E & forward & $\frac{\text { CACGACGTTGTAAAACGACACYAAI }}{\text { CAYAAAGAYATIGGCAC }}$ & \multirow[t]{2}{*}{$226 \mathrm{bp}$} & \multirow[t]{2}{*}{$\begin{array}{l}\text { Shokralla et al. } \\
(2015)\end{array}$} \\
\hline & Mini_SH-E & reverse & $\frac{\text { GGATAACAATTTCACACAGGCTTAT }}{\text { RTTRTTTATICGIGGRAAIGC }}$ & & \\
\hline \multirow[t]{3}{*}{$\begin{array}{l}\text { CR mini- } \\
\text { barcode }\end{array}$} & Tuna CR_F & forward & $\frac{\text { CACGACGTTGTAAAACGACGCAYG }}{\text { TACATATATGTAAYTACACC }}$ & \multirow[t]{3}{*}{$280 \mathrm{bp}$} & \multirow[t]{3}{*}{$\begin{array}{l}\text { Mitchell and } \\
\text { Hellberg (2016) }\end{array}$} \\
\hline & Tuna CR_R1 & reverse & $\frac{\text { GGATAACAATTTCACACAGGCTGG }}{\text { TTGGTRGKCTCTTACTRCA }}$ & & \\
\hline & Tuna CR_R2 & reverse & $\frac{\text { GGATAACAATTTCACACAGGCTGG }}{\text { ATGGTAGGYTCTTACTGCG }}$ & & \\
\hline
\end{tabular}

underlined segment indicates M13 tails 
Table 2. Combined results of full and mini-DNA barcoding for fish fillets tested in this study $(\mathrm{n}=120)$. Values are displayed as the number count.

\begin{tabular}{|c|c|c|c|c|c|}
\hline Category & $\begin{array}{l}\text { Number of } \\
\text { samples }\end{array}$ & $\begin{array}{l}\text { Identified to } \\
\text { species level }\end{array}$ & $\begin{array}{l}\text { Identified to } \\
\text { genus level }\end{array}$ & $\begin{array}{l}\text { Identified to } \\
\text { multi-genus level }\end{array}$ & $\begin{array}{l}\text { Samples with } \\
\text { species mislabeling }^{\text {a }}\end{array}$ \\
\hline Bass & 7 & 7 & -- & -- & 2 \\
\hline Catfish & 10 & 10 & -- & -- & 0 \\
\hline Cod & 10 & 5 & -- & $\begin{array}{l}5 \text { (Gadus and } \\
\text { Boreogadus) }\end{array}$ & 5 \\
\hline Halibut & 10 & 8 & 2 (Hippoglossus) & -- & 4 \\
\hline Mahi-mahi & 6 & 5 & 1 (Coryphaena) & -- & 0 \\
\hline Pangasius & 10 & 1 & -- & $\begin{array}{l}9 \text { (Pangasianodon } \\
\text { and Pangasius) }\end{array}$ & 3 \\
\hline Rockfish & 6 & 5 & 1 (Sebastes) & -- & 0 \\
\hline Rockfish/snapper & 2 & 1 & 1 (Sebastes) & -- & 2 \\
\hline Salmon & 10 & 10 & -- & -- & 5 \\
\hline Snapper & 3 & 3 & -- & -- & 3 \\
\hline Sole & 10 & 10 & -- & -- & 0 \\
\hline Swordfish & 10 & 10 & -- & -- & 0 \\
\hline Tilapia & 10 & -- & 9 (Oreochromis) & $\begin{array}{l}1 \text { (Oreochromis } \\
\text { and } \\
\text { Pseudocrenilabrus) }\end{array}$ & 0 \\
\hline Trout & 2 & 2 & -- & -- & 0 \\
\hline Tuna & 10 & 1 & 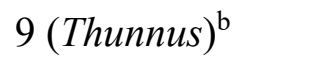 & -- & 1 \\
\hline Yellowtail & 4 & 4 & -- & -- & 2 \\
\hline Total & 120 & 82 & 23 & 15 & 27 \\
\hline
\end{tabular}

${ }^{a}$ Refers to samples with species substitution or unacceptable market name

${ }^{b}$ Eight of these samples were identified to the species level with the CR mini-barcode 
Table 3. Instances of species substitution detected in this study $(n=16)$

\begin{tabular}{|c|c|c|c|c|c|c|}
\hline $\begin{array}{l}\text { Sample } \\
\text { ID }\end{array}$ & Category & $\begin{array}{l}\text { Product name on } \\
\text { placard }^{\text {a }}\end{array}$ & $\begin{array}{l}\text { Product } \\
\text { description on } \\
\text { label }^{\text {a }}\end{array}$ & Expected species & $\begin{array}{l}\text { Price } \\
\text { paid (US } \\
\text { \$/kg) }\end{array}$ & Identified species \\
\hline P029 & Bass & $\begin{array}{l}\text { Seabass (Patagonian } \\
\text { toothfish) }\end{array}$ & $\begin{array}{l}\text { Seabass } \\
\text { (Patagonian Tooth } \\
\text { Fish) }\end{array}$ & $\begin{array}{l}\text { Patagonian toothfish } \\
\text { (Dissostichus eleginoides) }\end{array}$ & 88.18 & $\begin{array}{l}\text { Antarctic toothfish } \\
\text { (Dissostichus mawsoni) }\end{array}$ \\
\hline P101 & Bass & $\begin{array}{l}\text { Seabass Chilean } \\
\text { Portions Minimum } 5 \\
\text { oz Previously Frozen }\end{array}$ & $\begin{array}{l}\text { Seabass Chilean } \\
\text { Portions } \\
\text { Minimum } 5 \mathrm{oz} \\
\text { Previously Frozen }\end{array}$ & $\begin{array}{l}\text { Antarctic toothfish } \\
\text { (Dissostichus mawsoni) or } \\
\text { Patagonian toothfish } \\
\text { (Dissostichus eleginoides) }\end{array}$ & 94.01 & $\begin{array}{l}\text { Swordfish (Xiphias } \\
\text { gladius) }\end{array}$ \\
\hline P001 & Cod & $\begin{array}{l}\text { Fresh Wild Caught } \\
\text { Pacific Cod Fillets }\end{array}$ & $\begin{array}{l}\text { True Cod Fillet } \\
\text { Fresh }\end{array}$ & $\begin{array}{l}\text { Pacific cod (Gadus } \\
\text { microcephalus) }\end{array}$ & 30.86 & $\begin{array}{l}\text { Atlantic cod (Gadus } \\
\text { morhua) }\end{array}$ \\
\hline P031 & Cod & Pacific Cod & Pacific Cod Fillet & $\begin{array}{l}\text { Pacific cod (Gadus } \\
\text { microcephalus) }\end{array}$ & 33.07 & $\begin{array}{l}\text { Atlantic cod (Gadus } \\
\text { morhua) }\end{array}$ \\
\hline P063 & Cod & Rock Cod Fillet & $\begin{array}{l}\text { Fillet of Rock } \\
\text { Cod }\end{array}$ & $\begin{array}{l}\text { Rock cod (Lotella rhacina or } \\
\text { Pseudophycis barbata) }\end{array}$ & 8.82 & $\begin{array}{l}\text { Redbanded rockfish } \\
\text { (Sebastes babcocki) }\end{array}$ \\
\hline P061 & Halibut & Fresh Halibut Steak & Halibut Steak & $\begin{array}{l}\text { Atlantic halibut } \\
\text { (Hippoglossus hippoglossus) } \\
\text { or Pacific halibut } \\
\text { (Hippoglossus stenolepis) }\end{array}$ & 15.42 & $\begin{array}{l}\text { California flounder } \\
\text { (Paralichthys } \\
\text { californicus) }\end{array}$ \\
\hline P065 & Halibut & Halibut Steak & Halibut Steak & $\begin{array}{l}\text { Atlantic halibut } \\
\text { (Hippoglossus hippoglossus) } \\
\text { or Pacific halibut } \\
\text { (Hippoglossus stenolepis) }\end{array}$ & 15.43 & $\begin{array}{l}\text { California flounder } \\
\text { (Paralichthys } \\
\text { californicus) }\end{array}$ \\
\hline P069 & Halibut & Halibut Steak & Halibut Steak & $\begin{array}{l}\text { Atlantic halibut } \\
\text { (Hippoglossus hippoglossus) } \\
\text { or Pacific halibut } \\
\text { (Hippoglossus stenolepis) }\end{array}$ & 24.25 & $\begin{array}{l}\text { California flounder } \\
\text { (Paralichthys } \\
\text { californicus) }\end{array}$ \\
\hline P099 & Halibut & $\begin{array}{l}\text { Fresh Central Pacific } \\
\text { Halibut Fillet }\end{array}$ & $\begin{array}{l}\text { Fresh Central } \\
\text { Pacific Halibut } \\
\text { Fillet }\end{array}$ & $\begin{array}{l}\text { Pacific halibut (Hippoglossus } \\
\text { stenolepis) }\end{array}$ & 61.73 & $\begin{array}{l}\text { California flounder } \\
\text { (Paralichthys } \\
\text { californicus) }\end{array}$ \\
\hline P047 & Pangasius & $\begin{array}{l}\text { Frozen Red Swai } \\
\text { Fillet }\end{array}$ & $\begin{array}{l}\text { Frozen Red Swai } \\
\text { Fillet }\end{array}$ & $\begin{array}{l}\text { Sutchi catfish } \\
\text { (Pangasianodon } \\
\text { hypophthalmus) }\end{array}$ & 8.82 & $\begin{array}{l}\text { Blue-spotted stingray } \\
\text { (Neotrygon kuhlii) }\end{array}$ \\
\hline
\end{tabular}




\begin{tabular}{|c|c|c|c|c|c|c|}
\hline P019 & Snapper & Red Snapper Fillet & $\begin{array}{l}\text { Whole Clean Red } \\
\text { Snapper } \\
\text { Fresh/Wild }\end{array}$ & $\begin{array}{l}\text { Red snapper (Lutjanus } \\
\text { campechanus) }\end{array}$ & 13.19 & $\begin{array}{l}\text { Blackspotted rockfish } \\
\text { (Sebastes melanostictus) }\end{array}$ \\
\hline P117 & Snapper & N/A (no placard) & $\begin{array}{l}\text { Fresh Red } \\
\text { Snapper Sashimi }\end{array}$ & $\begin{array}{l}\text { Red snapper (Lutjanus } \\
\text { campechanus) }\end{array}$ & 132.28 & Madai (Pagrus major) \\
\hline P118 & Snapper & N/A (no placard) & $\begin{array}{l}\text { Premium Red } \\
\text { Snapper }\end{array}$ & $\begin{array}{l}\text { Red snapper (Lutjanus } \\
\text { campechanus) }\end{array}$ & 154.32 & Madai (Pagrus major) \\
\hline P074 & Tuna & $\begin{array}{l}\text { Yellowfin Ahi Tuna } \\
\text { Steak Previously } \\
\text { Frozen }\end{array}$ & $\begin{array}{l}\text { Tuna Yellow } \\
\text { Fin/Ahi Steak } \\
\text { Skin-Off } \\
\text { Previously Frozen } \\
\text { - CO }\end{array}$ & $\begin{array}{l}\text { Yellowfin tuna (Thunnus } \\
\text { albacares) }\end{array}$ & 22.05 & $\begin{array}{l}\text { Southern bluefin tuna } \\
\text { (Thunnus maccoyii) }\end{array}$ \\
\hline P035 & Yellowtail & N/A (no placard) & Sushi Yellowtail & Yellowtail (Seriola lalandi) & 55.12 & $\begin{array}{l}\text { Buri (Seriola } \\
\text { quinqueradiata) }\end{array}$ \\
\hline P104 & Yellowtail & N/A (no placard) & Yellowtail Kirimi & Yellowtail (Seriola lalandi) & 30.86 & $\begin{array}{l}\text { Buri (Seriola } \\
\text { quinqueradiata) }\end{array}$ \\
\hline
\end{tabular}


Table 4. Samples found to have unacceptable market names $(\mathrm{n}=11)$ according to the FDA Seafood List. Note: FDA recommends using the common name as the market name unless prohibited by regulation or law.

\begin{tabular}{|c|c|c|c|c|c|c|}
\hline $\begin{array}{l}\text { Sample } \\
\text { ID }\end{array}$ & Category & $\begin{array}{l}\text { Product } \\
\text { name on } \\
\text { placard }\end{array}$ & $\begin{array}{l}\text { Product } \\
\text { description on } \\
\text { label }\end{array}$ & $\begin{array}{l}\text { Identified species (common name } \\
\text { and scientific name) }\end{array}$ & $\begin{array}{l}\text { Acceptable } \\
\text { market name(s) } \\
\text { other than the } \\
\text { common name }\end{array}$ & Comments \\
\hline P085 & Cod & $\begin{array}{l}\text { N/A (no } \\
\text { product } \\
\text { name on } \\
\text { placard) }\end{array}$ & $\begin{array}{l}\text { Fresh Lind } \\
\text { Cod }\end{array}$ & $\begin{array}{l}\text { Pacific cod (Gadus } \\
\text { macrocephalus)/ } \\
\text { Arctic cod (Boreogadus saida)/ } \\
\text { Greenland cod (Gadus ogac) }{ }^{\mathrm{a}}\end{array}$ & $\begin{array}{l}\text { Cod or Alaska cod } \\
\text { (for Pacific cod) }\end{array}$ & $\begin{array}{l}\text { Possible misspelling } \\
\text { of "ling cod", a } \\
\text { vernacular name for } \\
\text { Molva molva }\end{array}$ \\
\hline P103 & Cod & $\begin{array}{l}\text { N/A (no } \\
\text { placard) }\end{array}$ & $\begin{array}{l}\text { Black Cod } \\
\text { Kirimi }\end{array}$ & Sablefish (Anoplopoma fimbria) & Sablefish & $\begin{array}{l}\text { Black cod is a } \\
\text { vernacular name for } \\
\text { sablefish }\end{array}$ \\
\hline P013 & Pangasius & $\begin{array}{l}\text { N/A (no } \\
\text { placard) }\end{array}$ & $\begin{array}{l}\text { Swai Basa } \\
\text { Fillet }\end{array}$ & 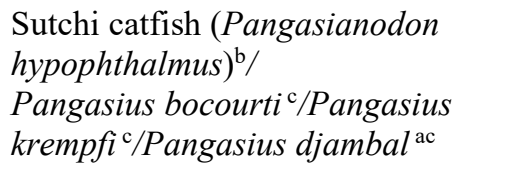 & $\begin{array}{l}\text { Swai or Sutchi or } \\
\text { Striped Pangasius } \\
\text { or Tra/Basa }\end{array}$ & $\begin{array}{l}\text { Swai and Basa refer } \\
\text { to two separate } \\
\text { species }\end{array}$ \\
\hline P039 & Pangasius & $\begin{array}{l}\text { Basa Fish } \\
\text { Fillet }\end{array}$ & $\begin{array}{l}\text { Red Fish Basa } \\
\text { Fillet S/C }\end{array}$ & 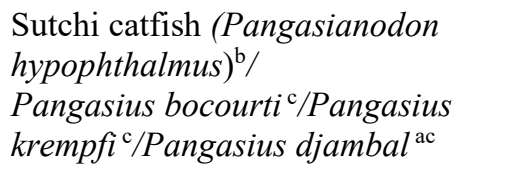 & $\begin{array}{l}\text { Swai or Sutchi or } \\
\text { Striped Pangasius } \\
\text { or Tra/Basa }\end{array}$ & $\begin{array}{l}\text { "Red fish" and basa } \\
\text { refer to different } \\
\text { species }\end{array}$ \\
\hline P092 & Rockfish/Snapper & $\begin{array}{l}\text { Fresh } \\
\text { Pacific } \\
\text { Snapper } \\
\text { Filet }\end{array}$ & $\begin{array}{l}\text { Pacific } \\
\text { Rockfish Fillet } \\
\text { Wild-Fresh }\end{array}$ & $\begin{array}{l}\text { Widow rockfish (Sebastes } \\
\text { entomelas) }\end{array}$ & $\begin{array}{l}\text { Rockfish, Pacific } \\
\text { Red Snapper }^{\mathrm{d}}\end{array}$ & $\begin{array}{l}\text { "Rockfish" and } \\
\text { "Pacific snapper" } \\
\text { refer to different } \\
\text { species }\end{array}$ \\
\hline
\end{tabular}




\begin{tabular}{|c|c|c|c|c|c|c|}
\hline P107 & Rockfish/Snapper & $\begin{array}{l}\text { Fresh } \\
\text { Rockfish } \\
\text { Red Snapper }\end{array}$ & $\begin{array}{l}\text { Rock Fish } \\
\text { Fillets }\end{array}$ & $\begin{array}{l}\text { Darkblotched rockfish (Sebastes } \\
\text { crameri)/ Northern rockfish } \\
\text { (Sebastes polyspinis)/ } \\
\text { Yellowmouth rockfish (Sebastes } \\
\text { reedi)/ } \\
\text { Vermilion rockfish (Sebastes } \\
\text { miniatus) }^{\mathrm{a}}\end{array}$ & $\begin{array}{l}\text { Rockfish, Pacific } \\
\text { Red Snapper }\end{array}$ & $\begin{array}{l}\text { "Rockfish" and } \\
\text { "Red snapper" refer } \\
\text { to different species }\end{array}$ \\
\hline P020 & Salmon & $\begin{array}{l}\text { Salmon } \\
\text { Fillet }\end{array}$ & $\begin{array}{l}\text { Fresh Salmon } \\
\text { Fillet }\end{array}$ & Atlantic salmon (Salmo salar) & Salmon, Atlantic & $\begin{array}{l}\text { "Atlantic" must be } \\
\text { specified }\end{array}$ \\
\hline P033 & Salmon & $\begin{array}{l}\text { N/A (no } \\
\text { placard) }\end{array}$ & Salmon & Atlantic salmon (Salmo salar) & Salmon, Atlantic & $\begin{array}{l}\text { "Atlantic" must be } \\
\text { specified }\end{array}$ \\
\hline P040 & Salmon & $\begin{array}{l}\text { Salmon } \\
\text { Fillet }\end{array}$ & $\begin{array}{l}\text { Salmon Fish } \\
\text { Fillet S/C }\end{array}$ & Atlantic salmon (Salmo salar) & Salmon, Atlantic & $\begin{array}{l}\text { "Atlantic" must be } \\
\text { specified }\end{array}$ \\
\hline P045 & Salmon & $\begin{array}{l}\text { Fresh } \\
\text { Salmon Fish } \\
\text { Fillet }\end{array}$ & $\begin{array}{l}\text { Fresh Salmon } \\
\text { Fish Fillet }\end{array}$ & Atlantic salmon (Salmo salar) & Salmon, Atlantic & $\begin{array}{l}\text { "Atlantic" must be } \\
\text { specified }\end{array}$ \\
\hline P050 & Salmon & $\begin{array}{l}\text { Salmon } \\
\text { Fillet Skin } \\
\text { On }\end{array}$ & $\begin{array}{l}\text { Salmon Fillet } \\
\text { Skin On }\end{array}$ & Atlantic salmon (Salmo salar) & Salmon, Atlantic & $\begin{array}{l}\text { "Atlantic" must be } \\
\text { specified }\end{array}$ \\
\hline
\end{tabular}

${ }^{\mathrm{a} B O L D}$ showed equivalent top matches to all species listed.

${ }^{\mathrm{b}}$ Although the common name for $P$. hypophthalmus is Sutchi catfish, non-Ictaluridae members of the Siluriformes (catfish) order, cannot legally use the term "catfish" in their market name (section 403(t) of the FD\&C Act (21 U.S.C. 343(t)).

${ }^{c}$ The FDA Seafood List does not have records for the following species: Pangasius bocourti, Pangasius krempfi, Pangasius djambal, and Pseudocrenilabrus multicolor.

${ }^{\mathrm{d}}$ Pacific Red Snapper is considered a vernacular name when used in interstate commerce, but it is an acceptable market name in California (California Code of Regulations $§ 103)$ 
Table 5. Summary of COOL noncompliance for the fish samples collected in this study. Values are given as the number count.

\begin{tabular}{|c|c|c|c|c|c|c|c|c|}
\hline \multirow[t]{2}{*}{ Category } & \multirow{2}{*}{$\begin{array}{l}\text { Samples } \\
\text { collected }\end{array}$} & \multirow{2}{*}{$\begin{array}{l}\text { COOL } \\
\text { non- } \\
\text { compliant } \\
\text { samples }\end{array}$} & \multicolumn{3}{|c|}{ Country of origin declaration } & \multicolumn{3}{|c|}{ Production method declaration } \\
\hline & & & $\begin{array}{l}\text { Domestic } \\
\text { (USA) }\end{array}$ & Imported & $\begin{array}{l}\text { Not Stated or } \\
\text { Unclear }\end{array}$ & Wild & Farmed & $\begin{array}{l}\text { Not Stated or } \\
\text { Unclear }\end{array}$ \\
\hline Bass & 7 & 3 & 0 & 4 & $\begin{array}{l}\text { Unspecified: } \\
\text { "Korea" or } \\
\text { "Korean" (2) } \\
\text { Not stated (1) }\end{array}$ & 6 & 0 & Not stated (1) \\
\hline Catfish & 10 & 3 & 7 & 1 & $\begin{array}{l}\text { Contradictory } \\
\text { information (1) } \\
\text { Not stated (1) }\end{array}$ & 1 & 8 & Not stated (1) \\
\hline Cod & 10 & 0 & 6 & 4 & 0 & 10 & 0 & 0 \\
\hline Halibut & 10 & 2 & 6 & 2 & $\begin{array}{l}\text { Contradictory } \\
\text { information (2) }\end{array}$ & 10 & 0 & 0 \\
\hline Mahi-mahi & 6 & 3 & 0 & 4 & Not stated (2) & 3 & 1 & $\begin{array}{l}\text { Not stated (1) } \\
\text { Unclear wording: } \\
\text { "Born, Raised, } \\
\text { Harvested China" (1) }\end{array}$ \\
\hline Pangasius & 10 & 2 & 1 & 7 & Not stated (2) & $1^{\mathrm{a}}$ & $10^{\mathrm{a}}$ & 0 \\
\hline Rockfish & 6 & 0 & 2 & 4 & 0 & 6 & 0 & 0 \\
\hline $\begin{array}{l}\text { Rockfish/ } \\
\text { Snapper }\end{array}$ & 2 & 0 & 1 & 1 & 0 & 2 & 0 & 0 \\
\hline Salmon & 10 & 3 & 0 & 9 & Not stated (1) & 1 & 7 & Not stated (2) \\
\hline
\end{tabular}




\begin{tabular}{|c|c|c|c|c|c|c|c|c|}
\hline Snapper & 3 & 1 & 0 & 2 & $\begin{array}{l}\text { Contradictory } \\
\text { information (1) }\end{array}$ & 1 & 1 & $\begin{array}{l}\text { Contradictory: "Farm } \\
\text { Raised" on placard } \\
\text { and "Wild" on label } \\
\text { (1) }\end{array}$ \\
\hline Sole & 10 & 1 & 9 & 0 & Not stated (1) & 10 & 0 & 0 \\
\hline Swordfish & 10 & 2 & $3^{b}$ & $7^{\mathrm{b}}$ & $\begin{array}{l}\text { Contradictory } \\
\text { information (1) }\end{array}$ & 9 & 0 & Not stated (1) \\
\hline Tilapia & 10 & 2 & 0 & 9 & Not stated (1) & 0 & 9 & $\begin{array}{l}\text { Unclear wording: } \\
\text { "BRN,RAISD\&HAR } \\
\text { VST CHINA" (1) }\end{array}$ \\
\hline Trout & 2 & 0 & 2 & 0 & 0 & 0 & 2 & 0 \\
\hline Tuna & 10 & 5 & $3^{b}$ & $6^{\mathrm{b}}$ & $\begin{array}{l}\text { Not compliant: } \\
\text { "Tahiti" (1) } \\
\text { Contradictory } \\
\text { information (1) }\end{array}$ & 7 & 0 & Not stated (3) \\
\hline Yellowtail & 4 & 1 & 0 & 3 & Not stated (1) & 2 & 1 & Not stated (1) \\
\hline Total & 120 & 28 & 40 & 63 & 19 & 69 & 39 & 13 \\
\hline
\end{tabular}

${ }^{a}$ One sample of Pangasius listed both farm raised and wild caught as the production method. This sample was considered to be COOL compliant due to the possibility of a commingled commodity (7 CFR §60).

${ }^{b}$ One sample of swordfish and one sample of tuna listed USA, Mexico, and Canada as the countries of origin. These samples were considered to be COOL compliant due to the possibility of a commingled commodity (7 CFR $\S 60$ ). 


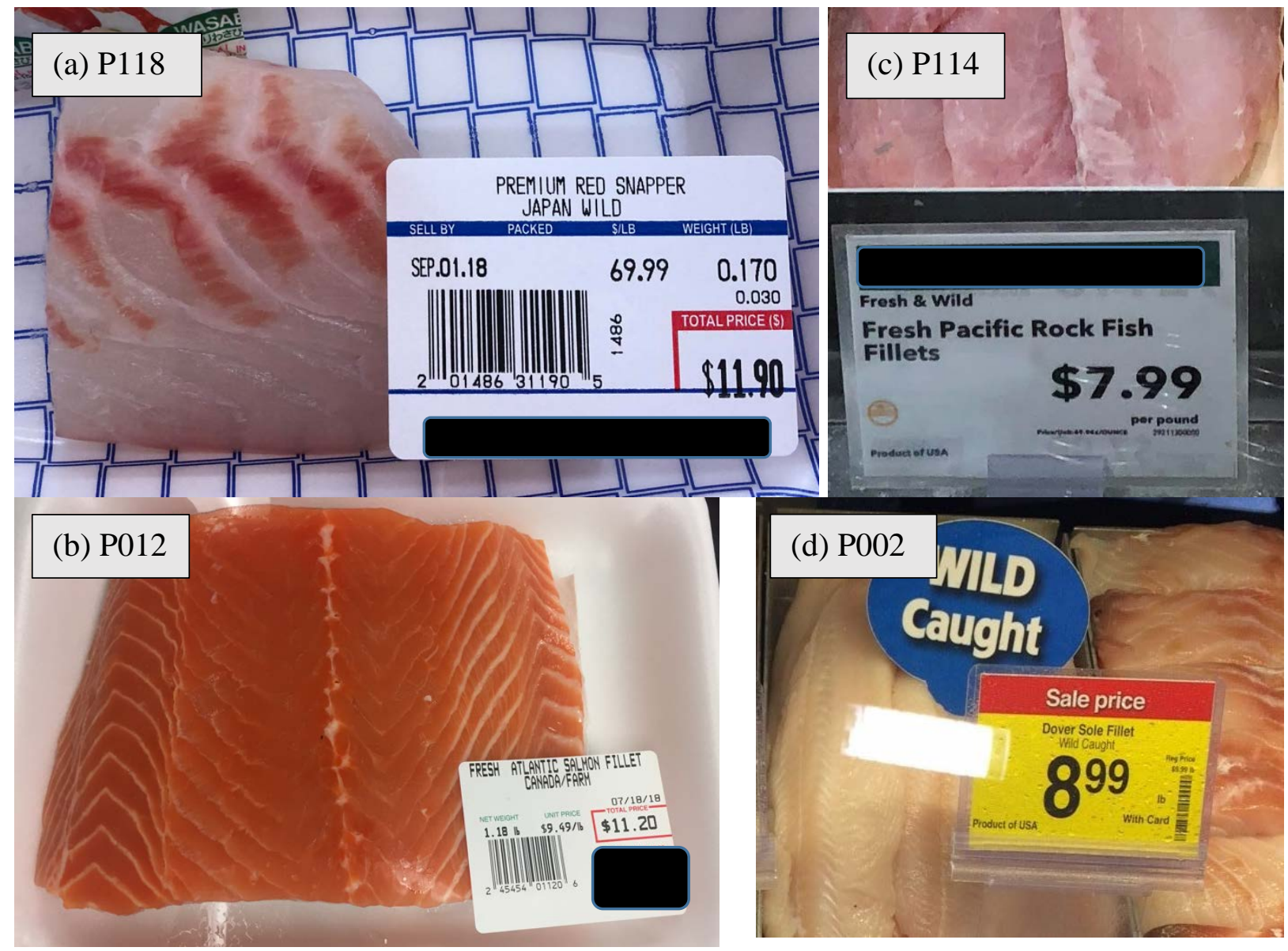

Figure 1. Examples of COOL compliant sticker labels (a-b) and seafood counter placards (c-d) on individually packaged products. Store names have been redacted from labels. 


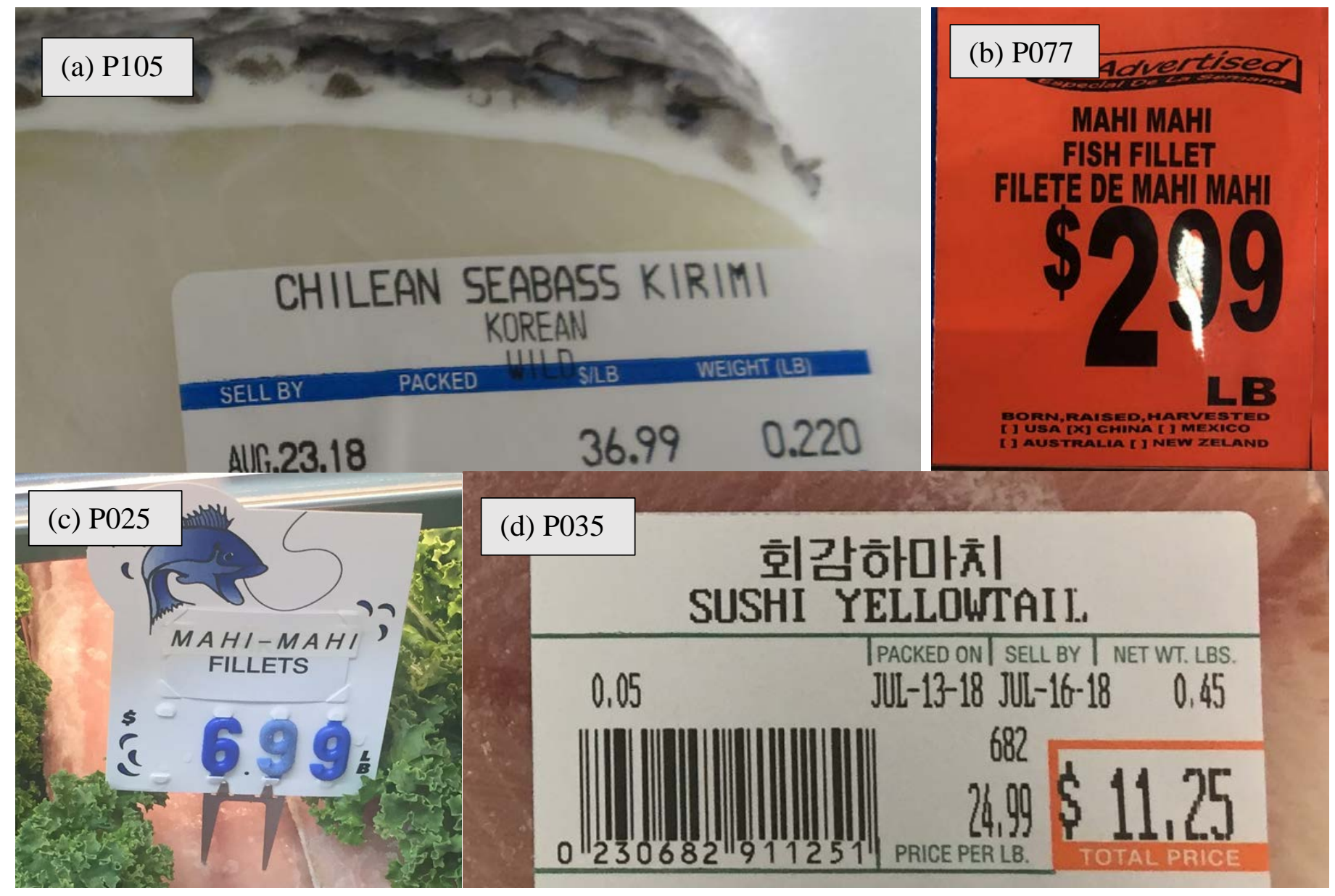

Figure 2. Examples of (a) COOL non-compliant sticker (invalid country name) on an individually packaged product (b) COOL non-compliant placard (unclear wording regarding production method) at the seafood counter (c) COOL non-compliant placard (no country or production method) at the seafood counter (d) COOL non-compliant sticker (no country or production method) on an individually packaged product 